\title{
羊毛繊維の水中における力学的挙動*
}

白樫㑆** 小 口 登**

\section{The Mechanical Behavior of Wool Fiber in Water}

\author{
by \\ Kan ShiRAKashi and Noboru OGuchi \\ (Department of Textile, Tokyo Institute of Technology, Ōokayama, \\ Meguro-ku, Tokyo)
}

The mechanical behavior of wool fiber in water is studied by the free damped vibrational method at low frequency (period $=4 \sim 5 \mathrm{sec}$ ) and large amplitude (maximum amplitude $=2 \%$ extension) under various static strains and temperatures. In order to measure the stationary viscoelasticity, the logarithm of double amplitude must be decreased linearly with the vibration. In the case of wool in water, these straight lines (plots of logarithm of the double amplitudes $\left(A_{N}\right)$ against successive vibration numbers $(N)$ ) are concave or convex about the axis of the successive vibration number $(N)$. There are three types of $\log A_{N} \sim N$ curves: Straight line and concave or convex against $\mathrm{N}$-axis. The above three types are assumed as follows:

(1) Straight line :

The breaking and reformation of the secondary bonds are in equilibrium and a stationary state is attained.

(2) Convex curve:

The reformation of the secondary bonds exceeds the breaking during the vibration.

(3) Concave curve :

The breaking of the secondary bonds exceeds the reformation during the vibration.

The above hypothesis may explain the mechanical behavior of wool in water at various conditions. This is shown as follows :

1. The wool fiber is extended in the state where the breaking of the secondary bonds exceeds the reformation of the bonds, but during retraction the reformation exceeds. The change of the viscoelasticity under extension and retraction is reversible within $0 \sim 30 \%$ extension region (Fig. 2 3).

2. During the stress relaxtation at $10 \%$ extension, the breaking of the secondary bonds exceeds and a stationary state is attained with the elapse of time (Fig. 4).

3. When the vibration contains the yield point, the reformation of the bonds exceeds the breaking under large double amplitude, and the breaking exceeds the reformation under small double amplitude (Fig. 5).

4. Under rising temperature at $10 \%$ extension, the breaking of the bonds exceeds and under falling temperature, the formation of the bonds exceeds (Fig. 6).

The temperature dependency of the relative Young's modulus is compared with the data of Meredith and Feughelman. The temperature coefficient of Young's modulus at Hookean region derived by some workers are as follows :

\begin{tabular}{c|c|c}
\hline $\begin{array}{c}\text { Temperature coefthcient of } \\
\text { Young's modulus of wool } \\
\text { fiber }\end{array}$ & Workers & Remarks \\
\hline$-40 \times 10^{-4} /{ }^{\circ} \mathrm{K}$ & R. Meredith & Dry and wet wool fiber \\
\hline$-57 \times 10^{-4} /{ }^{\circ} \mathrm{K}$ & M. Feughelman & Theoretical value \\
\hline$-70 \sim-90 \times 10^{-4} /{ }^{\circ} \mathrm{K}$ & M. Feughelman & From the creep experiment \\
\hline$-89 \times 10^{-4} /{ }^{\circ} \mathrm{K}$ & Authors & $\begin{array}{c}\text { Wool in water } \\
\text { Dynamic measurements }\end{array}$ \\
\hline & & \\
(Received Jan. 5, 1960)
\end{tabular}




\section{1. 緒言}

羊毛䋐維は絹繊維と同様に天然の蛋白質繊維で, そ の構造はきわめて複雑である，とくに力学的挙動を支 配する因子も，分子を構成するアミノ酸残基の種類の 多いこと, 側鎖の体積, 結晶性, 分子の可撓性, 分子 間および分子内 2 次結合, 分子間架橋, 吸湿による膨 潤， $\alpha$-ケラチンњ $\beta$-ケラチンの転移… などと多く, その全容を把握することは容易てはない.しかし分子 が可撓性に富み, シスチン結合により網状構造を形ち づくり，したがって本質的にはゴム状弾性であるが， 分子内および分子間の相互作用が強く, $\alpha$-ケラチンよ りも伸びた $\beta$-ケラチンが高エネルギー状態にあるた め，見かけは土ネルギー弹性が観測される。また，30 \%以上の伸長にはシスチン結合の切断が関与する.こ のような複雑な力学的状態は, Hookean region, yield region, および post-yield region に分けて考えられ ており，これらに対して， $\alpha$-ケラチン, $\beta$-ケラチンお よびシスチン結合の切断と流動がそれぞれ対応されて 研究されている。したがって, 各状熊の温度依存性も 異なる(たとえば 2 次転移点なと). 羊毛が水中で $30 \%$ 以内の変形を行なうときは, それからのひずみ回復は ほとんど完全に行なわれるが，大きいおくれ弾性を示 し，これに対し Eyring 流の速度論が導入されている。 また, 羊毛は膨潤度が大きく, 2 次結合が充分切断さ れると, エネルギー弾性を失なって,ゴム弾性に移行 し, supercontraction 存生じ, 弾性率の温度変化は正 となり, 統計論が応用される.このように, 羊毛はそ れぞれの状態により異なった手法により研究され, 力 学的状態が理解されており, いわゆる緩和時間の分布 関数なとによる一般的記述は少ないようである. 本実 験は水中における羊毛に対してひずみと温度を変えて， それぞれの状態における 2 次結合の力学的挙動に及ぼ す影響を検討した。

\section{（I）試料および測定法}

\section{2. 実験と結 果}

試料は Lincoln 種羊毛を用い, 実験は $15 \mathrm{~cm}$ の試 料をジュワーびん中の水中に保って行なった. 固有振 動の周期が 6.0 秒の振子型の振子に試料を取りつけて 自由減衰振動させ (周期は $4 \sim 5$ 秒の範囲にとどめる) 対数減衰率から粘性を, 周期からヤング率を求めた. 試料の代わりに弾性率既知の spring と粘性係数㫜知 の $25^{\circ} \mathrm{C}$ の水を用いて弾性および粘性の算出の基礎と した， $25^{\circ} \mathrm{C}$ の水中における羊毛の弾性および粘性と して (Hookean region について)

弾 性 率 $=2 \cdot 17 \times 10^{9} \mathrm{dyne} / \mathrm{cm}^{2}$

粘性係数 $=1 \cdot 70 \times 10^{8} \mathrm{dyne} \cdot \mathrm{sec} / \mathrm{cm}^{2}$ が求められたので,この值に対する比として表示する. 振幅の变化は光学的に 28 倍に拡大して印画紙に記
録した. 最大複振幅は $15 \mathrm{~cm}$ の試料に対して $3.8 \%$ (印画紙上約 $16 \mathrm{~cm}$ ) まで大きくすることが可能である が，最大複振幅が $2 \cdot 0 \sim 2.5 \%$ (印画紙上約 $8 \sim 11 \mathrm{~cm}$ ) の範囲内にはいるように実験した。振子型の測定器に は2 個の試料を対称に取りつける方法が多いがこれ らの測定器は伸長と収縮が同じ挙動の試料に対しては よいが，挙動が異なるものには原理的に不合理てある。 振幅の大きい本法では, 片方の試料として spring を 用い(クリープも緩和もしない), 近似的に振動の中心 の移動をなくした. Fig. 1 の $A_{1}, A_{2}, A_{3}, \cdots \cdots A_{N}$ を 求め, $\log A_{N}$ を $N$ に対してプロットし, その傾斜より 粘性を考え，5回の平均周期よりヤング率を求めた. ただし，Nは振動回数を表わす. $\log A_{N}-N$ 曲線につ ぎの三つの代表的な型がみられた.

(1) $\log A_{N}-N$ が值線 (值線型)

(2) $\log A_{N}-N$ が $N$ 軸に凸（うえに凹型）

(3) $\log A_{N}-N$ が $N$ 軸に凹（うえに凸型）

周期は $A_{N}$ の減少により 小さくなり(ヤング率は增大 する)，振幅依存性をわずかに有するが，測定精度内 の変動であるので, 本法ては平均值を用いた（1)は 一定の粘弾性を示すこと.（2）は粘性が $N$ に対して減 少すること.（3）は粘性がNに対して増大したり固体 摩擦項のある場合なとを示している。（2），(3)の対 数減衰率としては $N \rightarrow 1$ における切線を用いた。

\section{(II) 応力ーひずみ曲線と粘弾性}

Fig. 2 は試料を徐々に伸長し, おのおのの伸長度で 測定した結果である. Hookean region でしばしば粘 性が急増することがあり, 興味ある問題であるが, 羊 毛の力学的履歴と複振幅の大ささおよひチキソトロピ 一性に関係があり，詳細な測定はむずかしく，単に

Hookean region より yield region の移行には著大
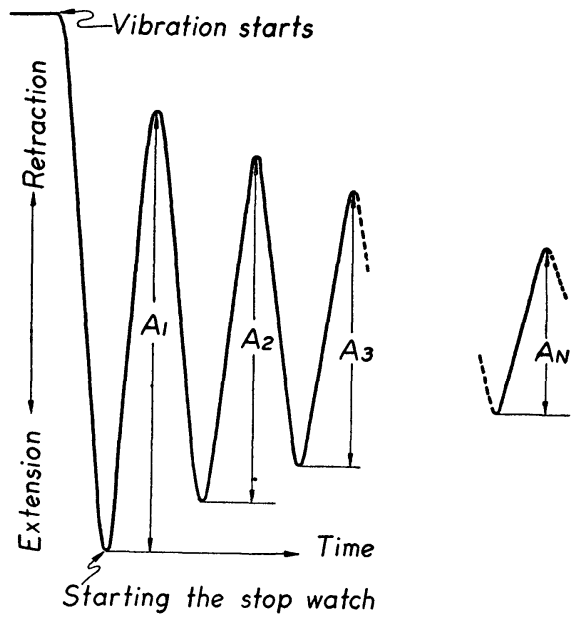

Fig. $1 A_{1}, A_{2}, \cdots \cdots A_{N}$ indicate double amplitudes of damped free vibration 


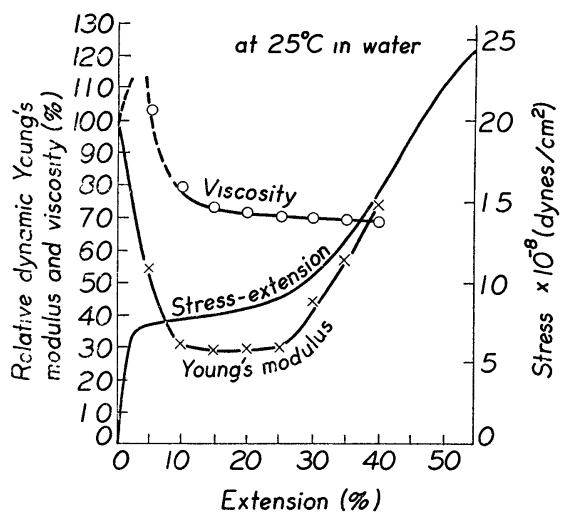

Fig. 2 Change of dynamic relative Young's modulus and viscosity of wool by stretching. Stress-extension curve is plotted also

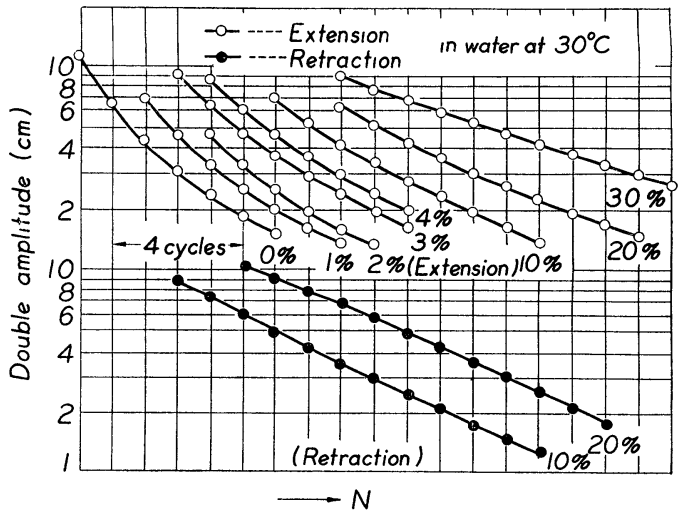

Fig. 3 The natural logarithm of successive double amplitudes of the pendulum oscillation are damped during the vibration. The percentage indicates static strain of the fiber

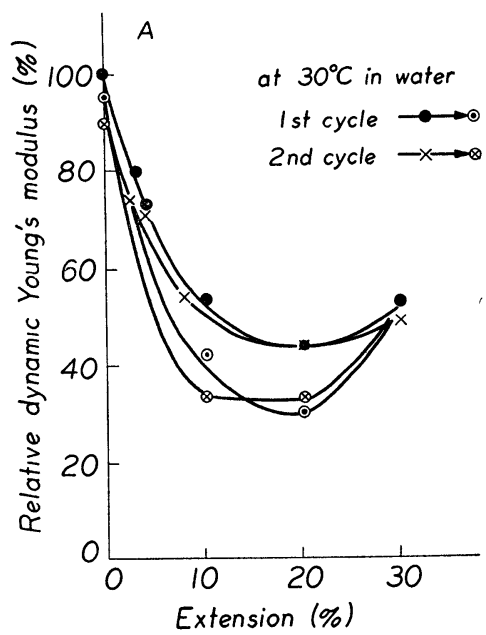

な抵抗があることを示すにすぎない.また，実際にも Hookean region の弾性率は変形速度によりいろいろ の值がみられる(後述). Yield region ではヤング率も 粘性係数も变化が少ないが, post-yield region では ヤング率が急増する．Fig. 3 に示すように，ひずみ回 復が完全である $30 \%$ 伸長率の範囲で静的に伸長・収 縮させて実験すると, $\log A_{N}-N$ 曲線に前記の ( 1 ), (2)，（3）の型が現われる，この各伸長・収縮による 粘弾性変化を Fig. 4 に示す.

(III) 応力緩和之振動特性

応力緩和中の粘弾性を振動法により求めたいのであ るが，これは厳密には不可能で，応力緩和も振動によ り中断され, 振動も応力緩和により不完全となる。こ のような危険をあえて犯して実験したのが Fig. 5 の $\log A_{N}-N$ である. 曲線 $B$ に添字してある数字は伸長

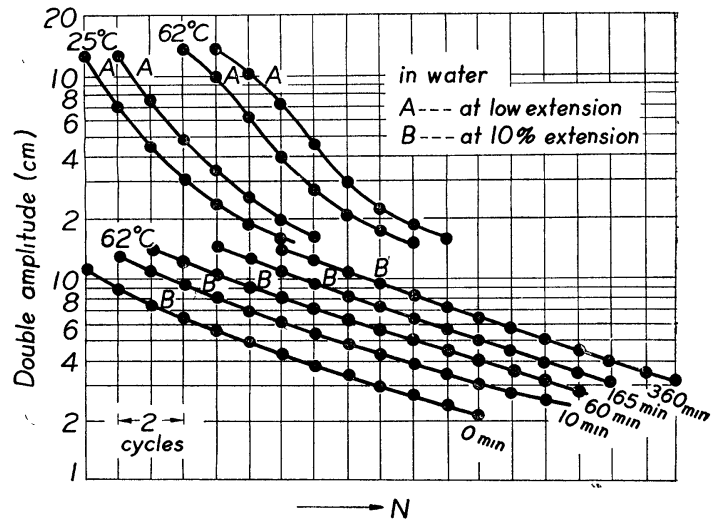

Fig. 5 Plots of natural logarithm of the double amplitude of damped free vibration against successive number of vibration at various times after $10 \%$ extension

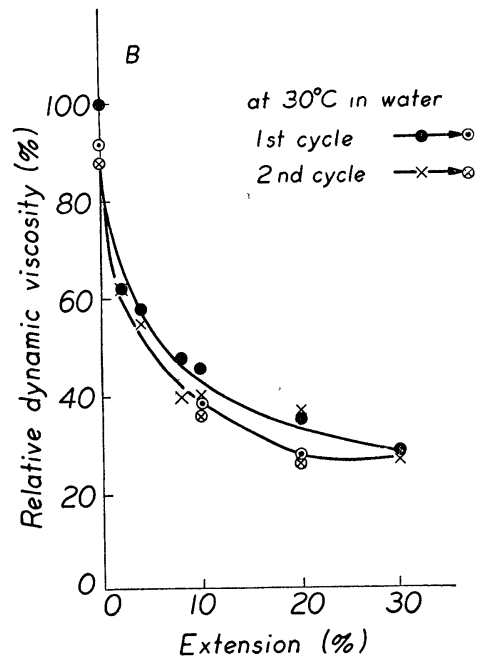

Fig. 4 Plots of relative Young's modulus and viscosity against static strain of extension and retraction cycles 
後振動開始までの時間で $0 \mathrm{~min}$ は伸長 “直後”を意味 する。これをみると, 未伸長の曲線 $A$ に比較して粘性 が減少すると同時に，わん曲が時間の経過とともにう えに凹型から直線型に移行していることがわかる，応 力緩和の同時測定は行なえないので, 測定值は示して ないが, 羊毛の応力緩和の測定は多く, 後に参考して 考察する.

(IV) Hookean region における温度変化

Fig. 6 に各温度ての Hookean region における振動 を示す。 $22^{\circ} \mathrm{C} \sim 40^{\circ} \mathrm{C}$ ぐらいまでは曲線はうえに山型 であるが, $40^{\circ} \mathrm{C}$ をこえると複振幅の大きい領域にう えに凸型の減衰が現われてわん曲点を生じる，わん曲 点は温度の上䄯とともに小さい複振幅側に移行する。 この挙動は, 後述するように, Hookean regionも単 にHookの法則に従う領域としては簡単に考えられず, 構造変化(構造破壊と再生)を伴なうことを示している。

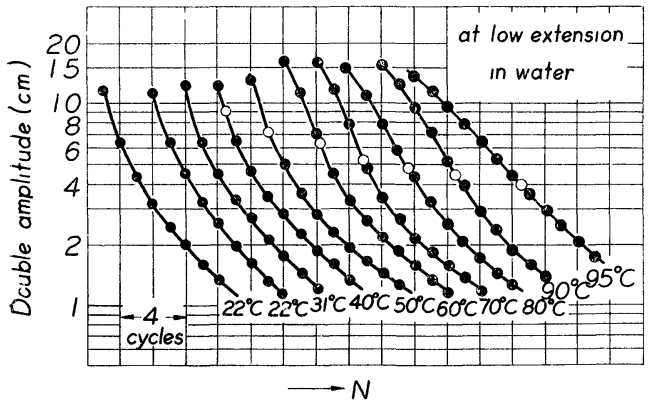

Fig. 6 The natural logarithm of double amplitude of the damped free vibration for varying temperatures near the yield point of wool. The filled circle indicates measured point and the open circle indicates point of inflexion of the curve

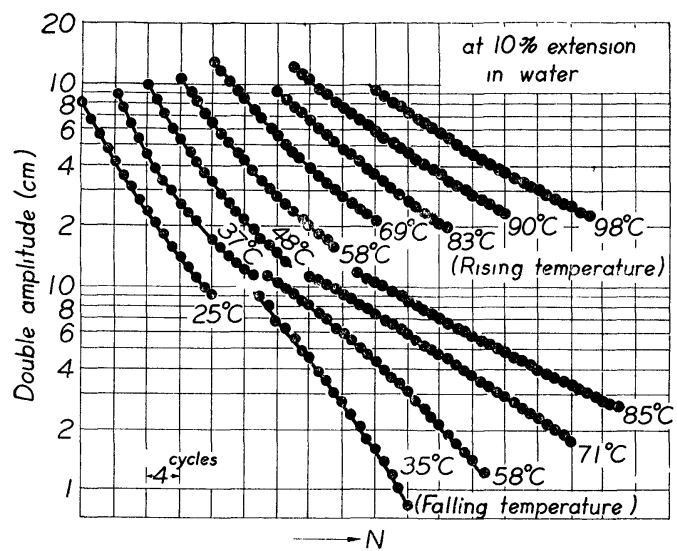

Fig. 7 The natural logarithm of double amplitude of the damped free vibration for varying temperatures at $10 \%$ extension of wool fiber

\section{（V） Yield region における温度変化}

Yield region は $\alpha$-ケラチンが $\beta$-ケラチンに転移す る領域であるといわれている， $25^{\circ} \mathrm{C}$ の水中て羊毛を $10 \%$ 伸長して 30 分そのまま保って振動させ, 以後温 度を平均 $2^{\circ} \mathrm{C} / \mathrm{min}$ で上昇させ，各温度でヤング率と 粘性係数を求め, さらに降温過程についてもこれと同 様の測定を行なうと，Fig. 7 に示すようになる。この 図によっても，升温と降温では $\log A_{N}-N$ 曲線に相 違のあることがわかる，年温時はうえに凹であって， 高温になるに従って值線になる，降温時は逆にうえに 凸型で，低温におけるほどわん曲が大さい。これを振 動開始時の值で整理すると, Fig. 8 のとおりになる. この図には Hookean region の温度変化も併記され ている.また，R. Meredith ²) M. Feughelman に よるヤング率の温度による变化を直線で示した.

\section{3. 考察}

水中における羊毛の力学的挙動を観湘する二, 三の 実験を試みたのであるが，これらの実験法はかならず しも従来の理論的根拠をもつ実験から判断して有効適 切な実験法ではないかもしれない。たとえば，応力一 ひずみ曲線を求めながら(階段的伸長を行ないながら) それぞれの伸長状態で振動実験を行なうなとはかえっ て問題を複雑にするようにみえるが，羊毛のようにシ スチン結合によって網状構造が形成されていて，水中 で $30 \%$ 伸長しても容易に切断しないような場合には， このような実験もいろいろ有益な知見を与えるものと 思われる。

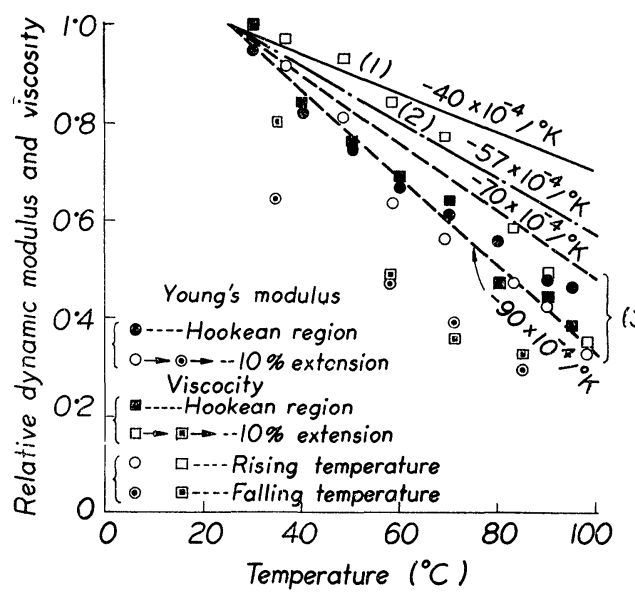

Fig. 8 The temperature dependence of the dynamic Young's modulus and viscosity at Hookean region and yield region is compared with the data of Meredith and Feughelman of the same.
(1) R. Meredith
(2) M. Feughelman
(theoretical) and
(3) M. Feughelman

(experimental) 
Hookean region の特異な力学的性質について, 羊 毛はとくに注目されており, Hookean regionなる名 称から判断しうるような単純なものではなく，rheological でしかも構造变化を伴なう複雑なものである. M. Feughelman も指摘しているように，約 1 秒の response をもつ装置で測定した瞬間的ひすみの $75 \%$ は時間的に伸ひたクリープであり, 残り $25 \%$ 真の 瞬間的な(時間のオーダが $10^{-5} \mathrm{sec}$ ) ひずみであると いっている. そうして Sikorski および Woods は, ヤング率に及ほす荷重速度 $\rho\left(\rho=\frac{d f}{d t}\right)$ の影響は $\log _{e} \rho$ の factor で直線的にきいているという。本実 験では Hookean region のヤング率として $2 \cdot 17 \times 10^{9}$ dyne $/ \mathrm{cm}^{2}$ を得ているが, 振動周期の $4 \sim 5$ 秒より判 断してもかなり小さい值として測定されている。これ は最初の变形(伸長)より直接求めたものでなく，つき の収縮から以後の数回の振動の平均から求めたことが 大きな原因であると思う．M. Feughelmanは $2 \times 10^{10}$ dyne $/ \mathrm{cm}^{2}$ を実測しているが, 真の瞬間弾性として Chaikin および Chamberlainの $8 \times 10^{10}$ を用いると, クリープによるひずみからのヤング率は $2 \cdot 67 \times 10^{10}$ dyne $/ \mathrm{cm}^{2}$ となるとした。これと本実験結果と比較し ても 1 けた異なっている。しかし, Hookean region のヤング率(水中)の温度係数を比較すると, Fig. 8 に 示すように, M. Feughelman は $1 \mathrm{c}$ ) $-70 \sim-90 \times 10^{-4}$ $1{ }^{\circ} \mathrm{K}$ と実测し, Burte-Halsey の two-state モデルに よる計算值として $-57 \times 10^{-4} /{ }^{\circ} \mathrm{K}$ を算出しているが, この実験では M. Feughelman の実測值 $-90 \times 10^{-4}$ $/{ }^{\circ} \mathrm{K}$ にほぼ近い. R. Meredith によるものは約 -40 $\times 10^{-4} /{ }^{\circ} \mathrm{K}$ であり, M. Fenghelman の理論值には近 いが実測值とはだいぶ違うようであり，本実験結果と も差が大きい.Fig. 8 には yield region (10\%伸長 率) のヤング率の温度依存性を併記してある。昇温時 と降温時でヒステリシスは認められるが, 温度勾配は Hookean region とあまり変わらないことがわかる.

つぎに，自由減衰振動により動的にヤング率および 粘性係数を求める実験をしたのであるが, $\log A_{N}-N$ の関係について図上三つの代表的な型がみられたこと は前に指摘してある。この三つの型がそれぞれつぎの ような構造变化に対応するものと仮定して考察する。 すなわち，

1. $\log A_{N}-N$ が直線になるのは, 羊毛の 2 次結合 が振動中に切断, 再結合の平衡状態にあるとみられ, 振動は定常状態である.

2.上記の曲線がうえに凹になるのは, 振動中 2 次 結合の切断が再結合より優勢であるような非平衡状態 である。

3.上記の曲線がうえに凸になるのは, 振動中, 切 断された 2 次結合の再生が優勢であるような非平衡状
態である.

このような仮定のもとに $\log A_{N}-N$ の実測結果を みると, Fig. 3 は Hookean region ではうえに凹型 であるが，こ0\%伸長状態に近づくに従って直線になり， 2 次結合の切断と再生が平衡することがわかる.また, $20 \%, 10 \%$ 収縮させると, 同じ伸長率でも伸長過 程に比較して収縮過程は 2 次結合の再生が優勢である ことがわかる．図は省略したのであるが，同じ試料に 対してさらに0〜30\%の伸長および収縮を行なっても， 第 1 回の伸長, 収縮と類似の $\log A_{N}-N$ が得られ,

Fig. 4 にこの結果を示してある.

応力緩和と組み合わせた Fig. 5 も $\log A_{N}-N$ は時 間の経過とともにうえに凹より直線の型に移行するこ とがわかる. R. Meredith の著書よりみても, $62^{\circ} \mathrm{C}$ の水中で $10 \%$ 伸長し，360分放置して応力緩和すれば， 水素結合に基づく応力緩和はほぼ完了しているものと 考えられ，その過程が $\log A_{N}-N$ において直線化と なって現われているものと思う. Fig. 6 の Hookean region の (Yield point が含まれていると考えられる が）振動の温度变化をみても, 室温に近いところでは, 同じ複振幅を比較しても，2次結合の切断が優勢であ るが, $40^{\circ} \mathrm{C}$ 以上の温度になると複振幅の大さいとこ ろで 2 次結合の再生の優勢の部分が現われてきて， $\log A_{N}-N$ にわん曲点がみられ, $90^{\circ} \mathrm{C}$ 以上の高温で は温度による 2 次結合の切断, 再生に及ぼす影響がみ られて, $\log A_{N}-N$ は全般的に值線化し定常化する。

Fig. 7 は $10 \%$ 伸長した Yield region における振 動であるが，これも昇温するに従ってうえに凹の曲線 が直線化されることがわかる，降温時をみると，同温 度の䒜温時に比較してはるかに直線的またはうえに凸 になっている.これは㫒温時の 2 次結合の切断過程に 比較して, 降温時の 2 次結合の再生を示している.

Hookean region の粘弾性の温度变化と yield region のそれとを併記すると Fig. 8 、になるが yield region における值の舁降温のさいのヒステリシスはそうとう に大きいが，これは年降温の速さによるものか，ある いは $10 \%$ 伸長の応力緩和や疲労によるものかは判明 しないが，前者によるものが大きいと思われる.

なお（3)のうえに凸の型式のものはわすかである が固体摩擦項の存在が認められた. 粘塑性体としてし ばしば注目される特性も, 以上の論旨をもってすると き，構造の形成過程に関係があることになる。

\section{4. 結}

び

羊毛綫維にかきらず, 繊維は応力緩和, クリープ, 応力ーひすみ関係なといすれも大変形で論しられるこ とが多く，また異なった手法による研究が盛んであ る.これらは実験のタイムスケール, 温度, 静的ひず み, 振動振幅などで統一されることが望まれている. 
羊毛に関してはこれに対し，多くの研究者によりクリ ープ測定が行なわれ, Hookean region および yield regionの結合の切断が繊維の長さに及ぼす影響や, 瞬 間的弾性值の分子論的または rheological な知識を提 供したものとして注目すべき手法であると思われる。 本実験は異なる手法による测定結果の統一に有効と思 われる二, 三の組合せ実験を行なって従来の結果の裏 付けと新しい解釈とを試みた。

\section{参考文 献}

1) A.R. Haly., M. Feughelman, Textile Res. J., 27, 919 (1957)

2) R. Meredith, "Mechanical Properties of Textıle
Fibres" North-Holland, Amsterdam, 1956

3）三宅彰, 物性論研究, 39, 121 (1951)

4) H.D. Holland, G. Halsey and H. Eyring, Textile Res. J., 16, 201 (1946)

5) M. Feughelman, J. Textile lnst., 49, T36́1 (1958)

6) J. Sikorski, H.J. Woods, Leeds Philosophical Soc., (Science Section), Proc. V.5. Pt. 4, 313-7 (1950)

7) M. Feughelman, A.R. Haly, and B.J. Rigby, Textile Res. J., 24, 311 (1959)

8) O. Ripa and J.B. Speakman, Textile Res. J., 21, 215 (1951)

9) M. Feughelman, J. Textile, Inst., 45, T630 (1954)

10) H. Burte and G. Halsey, Textile Res. J. 17, 465 (1947)

11) M. Chaikin and N.H. Chamberlain, J. Textile Inst., 46, T-44 (1955)

12) B.J. Rigby J. Textile Inst., 49, T-379 (1958)
放射線照射ポリエチレンの動力学的挙動 (Dynamic Mechanical Behavior of Irradiated Polyethylene) by C.W. Deely, J.A. Sauer and A.E. Woodward, J. App. Phys., Vol. 29, No. 10 (Oct. 1958) pp. 1415-1421, 図 4, 表 1

$2 \cdot 9 \times 10^{18} \mathrm{nvt}$ ぐらいまでの中性子を照射した高密度 ポリエチレン $\left(\right.$ Marlex-50 $\left.50^{\circ}\right)$ と $\mathrm{Co}^{60} \gamma$ 線を最高 $10^{6}$ rep ぐらい照射した低密度ポリェチレンについて粘弾性実 験を行ない, $80^{\circ} \sim 450^{\circ} \mathrm{K}$ の温度領域で弾性率と弾性 損失 $\tan \delta$ の温度变化を求めて照射効果をポリエチ レン両者について比較している. $\tan \delta$ のつの極值 に関しては両者ほとんと同一傾向であるが， $\beta$ 極值は 高密度ポリエチレンではかなり高度の照射になって現 われるから，側鎖のほとんと考えられない未照射試験 片は照射により側鎖または架橋結合が発生することを 示している．また $\beta$ 極值は低密度ポリェチレンのほう が高さも面積もともに高密度ポリエチレンのそれより 大きいが，これは低密度ポリエチレンの側鎖の多いこ とによる．照射とともに弾性率のエントロピー弾性へ の転移温度が低くなるのは, 結晶の融解が照射により 低温で起こり始めるためである。またェントロピー弾 性温度領域での弾性率から架橋度を計算し両者を比較 している。

（伊藤勝彦）
繊維状マットの連続成形法 (Continuous Forming of Fibrous Mat) by P.E. Fuerst, Modern Plastics Vol. 36, No. 2, (Oct. 1958) pp. 115 117, 120, 図 6, 表 2 , 文献 5

補強材に樹脂を含浸しプレスする積層法は量産に適 しないので湿式法で繊維状補強材より無方向性マット を得て樹脂により積層する連続製造装置が造られた。 これは中央に多数の穴のある回転ドラムがあり，この 上を非常に細い不銹鋼金網が回っている．ドラムの左 半部は密閉室となっていて，スクリーンの出口と入口 には合成ゴムロールが取りつけてあり，これに圧力を 加えてスクリーンに押しつけてあるから，空気や泥状 物は密閉室から噴出しない，樹脂およひ繊維状補強材 を混合した泥状物は圧力を加えて下部入口より送り込 み，スクリーン上に析出させる．次に圧縮空気で乾燥 させる．化粧板の積層を例にとれば適当な割合の新聞 紙とクラフト紙をハイドロパルパーにて泥状物にし， 次に水に不溶性フェノール樹脂粉末を加えこれを連続 製造装置にかける，空気による乾燥は樹脂の反応を進 めないため昇温しないよう注意する。この方法によっ て造られた積層板の抗折力が試験され，原料のクラフ 卜紙の含有率と直線的関係が示されている．このよう な湿式方法は強化プラスチックスにおける乾式風圧に よるガラス繊維のプレフォーミングにも利用でき，無 方向性で厚さの均一性もよい.

（伊藤勝彦） 